\title{
Assessment of Economic Risks in the Context of Strategic Enterprise Management
}

\author{
By Iryna Sievidova ${ }^{1}$, Elina Pakhucha ${ }^{2}$, Volodymyr Chumak $^{1}$, Lyudmila Shovkun ${ }^{2}$, \\ Artem Novikov ${ }^{2}$, Ivan Zakharov ${ }^{2}$, Oleksandr Skrypnyk ${ }^{3}$
}

\begin{abstract}
It is established that for the effective functioning and ensuring a high level of competitiveness of agricultural formations it is necessary to qualitatively develop all the constituent elements of the resource potential of the business entity. The main place in this belongs to the assessment and effective use of fixed assets, material, labor, financial, information components of the resource potential of the agricultural enterprise as a basis for successful and socio-economic development of the whole system. It is determined that the strategically oriented resource potential of agricultural formations is the availability of a sufficient number of quality resources of the economy and strategic competencies in the management to form and implement a strategy of action to achieve the goals of the enterprise. Methods for assessing the effectiveness of resource management of agricultural formations are studied. The method of determining the integrated indicator of the efficiency of the resource potential of the enterprise in terms of financial, material and labor resources is considered. Integral assessment allows you to compare the achieved level of management efficiency as a whole resource potential of the enterprise and its individual components for a certain period, for a better understanding of the situation, the period is chosen not less than 5 years. Formed stages of the process of forming strategic management of resource potential of agricultural formations which include strategic analysis, development of strategic goals, formation of strategic standards, strategy selection depending on the level of resource potential, formation of measures to ensure effective strategy implementation, evaluation and control of the proposed strategy. The assessment of the level of efficiency of resource potential management and its components of agroformation is carried out and the matrix of actions according to the reached level of efficiency of resource potential management is filled. The calculation of single, group, complex and integrated indicator of efficiency of management of resource potential of agroforming is carried out. The defined level remains only at a sufficient level, which necessitated the formation of an overall strategy for resource management. A system of strategic management of resource potential is proposed, which demonstrates the process of formation of resource potential and exerts managerial influence on economic processes and its strategic development. The system of strategic management of resource potential is primarily focused on the effective implementation of the functions that underlie agricultural formation. The basis of the developed system was the task of rational and balanced formation of resource potential and to ensure the competitiveness of the economy.
\end{abstract}

Keywords: management, strategy, resource potential, agricultural formation, system of strategic management

\section{Introduction}

The increasing competitive tensions, search for the ways of ensuring the country's food security, specific aspects and features of agriculture, conditions of economic activities

\footnotetext{
${ }^{1}$ Kharkiv National University of Internal Affairs, Ukraine

${ }^{2}$ Kharkiv National Agrarian University named after V.V. Dokuchaev, Ukraine

${ }^{3}$ Kharkiv Petro Vasylenko National Technical University of Agriculture, Ukraine

*Corresponding Author
} 
have shaped the conditions, which underpin the emergence of new forms of business organization that guarantee achieving business goals by business entities. The functions of agricultural sector, which include meeting the demand for various products, creation of interdependencies with the market, adaptation to natural and economic conditions, blending of resources, development of production infrastructure, are assuming importance. Under the modern market economy, different forms of ownership create the basis for different forms of business organization. The agricultural enterprises, which can help to protect the economic interests of agricultural producers and promote the socioeconomic development of rural areas, are one of such promising forms of business organization.

The country's economy is now developing under the conditions of market transformations and is characterized by updating of the main elements of production potential. Noncompliance with the rational use of natural and material resources, violation of the forms of labor involvement in the system of economic relations, disparities in the process of formation of production potential in the agricultural sector have led to violation of the system of reproduction and sustainable development of its elements. That being the case, the resource potential should be regarded as a set of interrelated resources that can be used in different areas of business activities.

The changes in the external environment dictate new terms for organizing the strategic management of the enterprise, resource potential in particular. While the life cycle of the enterprise is improving, its goals are constantly changing, which requires organizing the effective strategic management to rationally allocate the resource potential.

Thus, the effective management system is becoming important for ensuring the competitiveness of agricultural enterprises because it promotes timely mobilization of basic resources and innovations for the sustainable development of the system itself in a changing environment. If a business entity timely implements knowledge, skills and competencies, which meet the needs of society, this gives competitive advantages and ensures success in market activities.

The agricultural enterprise is a complex form of organization of business activities in the agricultural sector, so to create and develop resource potential with a more complex system, it is necessary to develop a new management system. Primarily, the system of management of the agricultural enterprises' resource potential should focus on the needs of consumers, increasing the efficiency of business activities and building a permanent base of partners. In the modern business climate, resilience to the crisis situations, which are directly related to insufficient investment, reduced production and escalating competition between importers and foreign producers, is assuming importance.

The efficient use of available resources and opportunities for the development of agricultural enterprises and searching for new ways of increasing their effectiveness, will enable reducing costs, improving the quality of manufactured products, optimizing the use of production facilities, achieving competitive advantages and increasing their share in the target market. Therefore, the main task is to develop the resource potential and respond quickly to changes, which will lead to acquiring new competencies. The assessment of the enterprise's resource potential and sustainable development is one of the tools of its management system.

The main task of strategic management is to ensure the rational allocation of resources of 
agricultural enterprises between the main areas of their activities and to efficiently use the resources in order to address strategic goals. The strategic management of the agricultural enterprises' resource potential should be manifest in the development of resource strategies that would address the tasks assigned: to determine resources needed for longterm activities; establish the resource consumption rate; establish tolerable limits for the use of resources, determine the strategic level of necessary resources and establish the directions of their use; create an efficient logistical system; apply logistical approaches to the development and implementation of resource strategies.

\section{Literature Review and Problem Statement}

In the paper (Salunm, 2012), it is proposed to define the enterprise's resource potential as a complex, multifaceted structure, including qualitative, functional, space, time, organizational and economic structures that meet modern goals of formation, development, reproduction and modernization of the company's resource potential. Therefore, at the stage of decentralization the system of strategic management of resource potential must be focused primarily on improving producers' effectiveness and competitiveness by setting priorities for building and development of an optimal sectoral structure.

The paper (Oliinyk, 2017) considers the subject matter of the "resources" and "potential" concepts and comes to the conclusion that the strategic management of the enterprise's resource potential allows increasing its competitiveness. It proposes to introduce modern management concepts based on the use of automated ERP and CRM systems.

The article (Kostyrko at al. 2020) dwells on the problems and factors influencing the efficient use of resources on the basis of the study of agricultural enterprises' development and resource potential. Based on the results of testing the methodological approach to the study of resource potential, the article identifies the main determinants that limit the efficiency of use of resource potential, set the priorities of resource allocation and increase labor productivity of agricultural enterprises. They are as follows: implementation of the programs of state support of innovative resource-saving technologies for the agricultural production; increase of technical and technological potential due to the attraction of investment credits, lease and partner programs; introduction of effective financial instruments; opening a transparent and clear land market.

In the course of research (Vasylyk, 2018) the methods of assessing the effectiveness of management of the enterprise's resource potential were improved. Now they include the calculation of individual, group, complex indicators for each of the components of resource potential and further reduction of calculations to the cumulative indicator. The assessment should be based on the components of resource potential: the potential of material resources, labor and fixed assets (three components of production potential), as well as financial and information potential.

The paper (Malinoshevsk, 2019) identifies the methodological approaches to assessing the quantitative and qualitative indicators of the results of strategic activities of agricultural enterprises, which characterize their market performance. It proposes the measures ensuring the strategic development of agribusiness entities, including, in particular, the improvement of legal framework at the national level, laying down regional strategic 
development programs, as well as support for agricultural enterprises and individual projects.

The resarch (Chyrva, 2016) identifies the conditions and tools for the effective management of resources of agricultural enterprises. It has developed such structural elements as the purpose, tasks, functions and stages of the strategic management of the enterprise's resource potential. It has established that the enterprise's strategic development is determined by the available qualitative resources that correspond to a particular agricultural enterprise, its strategic goals. It formulates the factors which are the basis of the mechanism of strategic management of the enterprise's resource potential.

The article (Zhmailova at al. 2014) lists the groups of factors influencing the formation of resource potential. For agriculture, the reproduction of all resources is identified as the main condition for their efficient use. The article proves that all elements of resource potential must be taken into account when performing simple or extended reproduction. It proposes to perform the resource potential reproduction in agriculture with the help of the state.

The paper (Nadzhib, 2020) proves that the resource potential is a unifying economic category; it includes such types of potential as production, personnel, infrastructure, financial, management, innovation and information potential. It characterizes each type of potential specified above and provides the general structure of resource potential.

To optimize the formation of resource potential of agricultural enterprises, the article (Demchenko, 2017) proposes an approach, including provision of socio-economic and environmental benefits for the balanced development of agriculture, formation of food security and export opportunities with due regard to WTO requirements. The article represents a comprehensive methodological approach to determining the mechanism of effective strategic management of the development of resource potential of agricultural enterprises, which will help to identify its most important components and develop effective measures to optimize these components.

The authors of the article (Khromushyna at al. 2018) justify the formation of resource potential of agricultural enterprises in compliance with the environmental and economic security requirements. The article states that ensuring the environmental and economic safety of activities of agricultural enterprises will promote the production of organic products and create conditions for increasing the enterprise competitiveness. As a result of the research, the scheme of formation of the resource potential of agricultural enterprises has been offered and justified based on the environmental and economic safety requirements.

The article (Smolych \& Tymoshuk, 2020) considers the resource potential management from the perspective of general management functions, such as resource planning, scheme of supplying resources to the enterprise, motivation and control. It has established that the ineffective management and use of resources leads to a decrease in the enterprise product quality and competitiveness. The article offers a ready-made scheme of resource management, ensuring the consistently high quality of enterprise products and contributing to additional optimization of financial costs, as well as to an efficient use of the organization's available and potential resources, which guarantees high performance. The author of the research (Romanii, 2019) highlights the main factors of effective strategic management of resource potential in the modern competitive environment; 
applying these factors will allow the agricultural enterprises to increase their competitive advantages in both domestic and foreign markets. The article offers a model of strategic management of the resource potential of agricultural enterprises, which has six stages.

The article (Sievidova, 2018) explores the international experience of constructing an organizational structure and a diagram of functional and coordinating relations of the main structural units of the wholesale market, taking into account many years of experience in the formation and development of a wholesale trade system in economically developed countries.

The paper (Mikhaylik, 2017) offers a mechanism of providing an enterprise with the financial potential management, which allows emphasizing elements useful for the financial potential formation on the basis of the enterprise's general strategy. In future, it can help to set goals for the financial potential formation, make a forecast, differentiate between the main areas of accumulation, formation and allocation of financial resources. It should be noted that the analysis of and control over the strategy of financial potential formation are important, as well as the use of analysis results to specify the strategic directions of enterprise development.

The article (Polyanin \& Dokukina, 2016) considers the theoretical and methodological problems of creation and use of strategic management mechanisms in agricultural organizations. The system results and evaluation of the results received during the calculations are the indicators that allow identifying the main problem of strategic management in a timely manner and focus on correcting the detected shortcomings. The systematized principles of management of the agricultural enterprise strategy facilitate the development of basic strategic goals. The conducted systematic analysis allows justifying the need for building models and developing the principles of strategic management.

As a result of research (Dudnyk, 2016), the system of investment mechanisms of resource potential formation has been presented. Analyzing and systematizing the views of scientists, the research paper considers the main issues of management of the efficient use of resource potential and role of investment mechanisms in this procedure. It justifies the types and interrelation of a general corporate strategy, resource strategy and investment strategy. It defines the managerial stages of investment strategy development.

The study (Senchuk, 2018) reveals the impact of resources and their structural interrelations on the availability of additional opportunities to improve the economic performance of agricultural enterprises. It identifies the criteria to classify agricultural enterprises having different resource provision. It highlights the difference between the resource provision and resource potential of agricultural enterprises. It justifies that unlike the structural elements of potential, the resource and production potential are not an object of reproduction.

The paper (Aranchii, Zoria \& Riznychenko, 2019) states that under the conditions of further institutional transformations in the country's economy, it is necessary to form a strategy for the development of agricultural enterprises while balancing the economic, environmental and social problems of their development. To form a strategy for further development of agricultural enterprises, the paper has analyzed the level and dynamics of their development under current conditions. It claims that the emerging negative trends in the agricultural sector only exacerbate the challenge of forming a strategy for the development of agricultural enterprises in order to further improve their performance and 
competitiveness in the food market which is an important sector of the country's economy and is able to increase the gross output and guarantee the country's food security.

The article (Feshchenko, 2015) deals with the methodological tools of result-oriented management of agricultural sector of the region's economy, which are based on the simulation modeling of production, economic and social processes. It has developed an algorithm for the system of forecasting, planning and formation of special comprehensive programs of agribusiness development, which differs from the already known algorithms by its system-based multifaceted approach to agribusiness development and includes the extended set of factors, strategies, mechanism of reciprocal modeling of changing environmental conditions and adjustment of the tasks of result-oriented management of agribusiness.

For the purpose of the general methodology of strategic management, the paper (Viatkina, 2014) places special emphasis on the need to use a systematic approach to the strategic management of resource potential of agricultural enterprises. It offers a concept of strategic management of the enterprise's resource potential. It states that the methodology of developing the strategic management of resource potential is based on the application of principles, specific methods of strategic decision-making and means of their practical implementation, which allow the enterprises to rationally use their resource potential.

The research (Collins, 2020) has established that the art of management, social capital, and human capital help determine when the HCHR strategy potentially leads to increased resources at the corporate level and when the companies are able to effectively manage and use these resources on the basis of strategic management in order to achieve competitive advantages.

The paper (Tereshchenko, 2015) analyzes the process of inventory of the property of agricultural enterprises. The resource potential inventory is the basis for the assessment and preparation of resource description, i.e. it discloses shortages and cases of stealing, confirms or disconfirms the accounting system data on the actual availability of resources. It offers to prepare resource descriptions in order to take into account changes in the market situation and production relations, improve the use of resources by agricultural enterprises and facilitate their systematic restructuring.

The article (Burkovska \& Romanchyk, 2016) considers the special aspects of strategic human resource management as the basis of strategic potential that affects the competitiveness of enterprises, determines the directions of their development. It has conducted the correlation and regression analysis of the dependence of labor productivity on the average monthly wage of agricultural workers.

The article (Kustrich, 2017) investigates the methods of enhancing the strategic management effectiveness and using the potential of agricultural enterprises. It has developed an innovative model of the system of the agricultural enterprise's resource potential. It determines the factors of external and internal environment that directly influence the resource potential system of an agricultural enterprise. It states that the efficiency of the use of production potential depends on the resource potential, demand, supply and other elements of market environment.

The publication (Shynkovych, 2019) considers the controversial issues concerning theoretical, methodological and practical aspects of the assessment of effectiveness of organizational and information support of anti-crisis management of agricultural 
enterprises. It has performed diagnosis of current problems and developed an approach to improve the assessment of effectiveness of organizational and information support of anti-crisis management of agricultural enterprises. It is done on a new multidimensional platform of high quality at a certain time interval, taking into account the specific aspects of operation of agricultural enterprises and their information and communication capabilities and competences. It determines preventive measures, tactical solutions and strategic horizons of business activities, which allows giving more detailed and unbiased practical recommendations for the selection of appropriate methods, tools and measures for crisis management, and this will facilitate risk and threat minimization and help to hold control under the destructive scenario.

The article (Tranchenko, at al., 2018) justifies the theoretical, methodological and methodical principles of strategic management of economic development of the agricultural sector in order to optimize its strategic management based on cognitive scenarios, supply and demand balance in the agricultural market, probabilistic modeling, which allows identifying growth areas, optimizing the sectoral composition of economy, improving the quality and efficiency of developed and implemented scenarios and strategies for the agribusiness development.

To ensure the long-term efficient operation and competitiveness of agricultural enterprises, it is necessary to fundamentally develop all resource potential components. The assessment and effective use of the enterprise's resource potential as the basis for successful system development holds an important place in addressing the issue. However, the main factor of business effectiveness of agricultural enterprises is the effectiveness of their strategic management system, which depends on the timely mobilization of necessary resource potential to ensure the system's sustainable existence at a certain stage of development.

Objectives of this study involve formulating and justifying a set of measures aimed at improving the efficiency of main resource potential components and identifying the areas of strategic management of resource potential based on the study of theoretical, methodological and analytical aspects of the resource potential of agricultural enterprises. To achieve this goal, we set the following objectives: to determine the methods of assessing the resource potential of agricultural enterprises, assess the current state of their resource potential, improve the system of strategic management of their resource potential.

\section{Specific Aspects of Measuring the Effectiveness of Resource Potential Management of Agricultural Enterprises and The Stages of Formation of Its Strategic Management}

From the economic point of view, the term "resource potential" of agricultural enterprises does not have a single generally accepted definition. Given the wide range of terms provided, most scientists agree on a more general definition and define the "resource potential" as a set of interrelated resources used for production. The size of the resource potential of business entities is determined by the amount of resources available to the enterprise (land, labor, material, financial, intangible, information resources). Improving the qualitative characteristics of agricultural sector and increasing the level of quantitative indicators of economic effectiveness are related to improving the efficiency of use of the 
resource potential.

The resource potential study uses a system approach, which includes the stage of initial qualitative analysis of the problem and goal setting. The system approach considers the object as a set of interconnected elements that has its "entrance", "exit", "connection with the external environment" and "feedback". From the point of view of "entrance" and "exit", there are four types of systems (Ulianchenko, 2009): "non-cybernetic" systems which have no entrance and no exit, i. e. closed systems; "cybernetic" systems which have an entrance and exit; systems that have an entrance, but no exit; "semi-cybernetic" systems having an exit, but no entrance.

The socio-economic systems are two-side open and cybernetic according to their type. The resource potential functions as a socio-economic system and has the characteristics of an open object-system which can accept and give information in the course of natural resource transformation due to the interaction of its constituent elements.

The presence of a large number of different combinations of objects-system transformation justifies the law of system transformations. As a system, the resource potential has a large number of types and methods of transformation in the process of production resource interaction. These transformations influence such components as production and economic relations, production structures, business unit size, methods of production organization, structure of resource balance. Thus, the system approach goes beyond the used definitions of resource potential as a system and has a broader meaning. The resource potential of agricultural sector can be considered using the following indicators (Bohatska, \& Kovalchuk, 2012): the average annual number of crop acres and agricultural areas, number of livestock animals, value of fixed production assets and current assets.

To determine the cumulative indicator of the enterprise's resource potential efficiency in terms of financial, material and labor resources, the following method proposed by (Shamanska, 2016) is used:

$$
\begin{aligned}
I_{I} & =\sum_{i=1}^{n} C_{W} \times R_{E}, \\
C_{I} & =\frac{(m \times n)-R_{i j}}{0,5 \times m \times n(n-1)}, \\
R_{E} & =\left(C_{R_{F}} \times R_{F}\right)+\left(C_{R_{M}} \times R_{M}\right)+\left(C_{R_{L}} \times R_{L}\right),
\end{aligned}
$$

where, $I_{I}$ is integrated indicator of the efficiency of the resource potential of the enterprise; $C_{I}$ - coefficient of weight of indicators of estimation of components of resource potential; $R_{E}$ - enterprise resources; $R_{F}$ - financial resources; $R_{M}$ - material resources; $R_{L}$ - labor resources.

Financial resources $\left(R_{F}\right)$ are determined by the formula:

$$
R_{F}=\left(k_{1} \times F_{1}\right)-\left(k_{2} \times F_{2}\right)+\left(k_{3} \times F_{3}\right)+\left(k_{4} \times F_{4}\right)+\left(k_{5} \times F_{5}\right)+\left(k_{6} \times F_{6}\right)+\left(k_{7} \times F_{7}\right),
$$

where, $k_{i}$ is coefficient of the weight of indicators for assessing financial resources; $F_{1}$ equity capital concentration ratio; $F_{2}$ - financial dependence ratio; $F_{3}$ - the ratio of the provision of working capital with its own working capital; $F_{4}$ - current liquidity ratio; $F_{5}$ quick liquidity ratio; $F_{6}$ - ratio of absolute liquidity; $F_{7}$ - return on equity. 
Material resources $\left(R_{M}\right)$ are determined by the formula:

$R_{F}=\left(k_{1} \times M_{1}\right)-\left(k_{2} \times M_{2}\right)+\left(k_{3} \times M_{3}\right)+\left(k_{4} \times M_{4}\right)+\left(k_{5} \times M_{5}\right)+\left(k_{6} \times M_{6}\right)+\left(k_{7} \times M_{7}\right)$,

where, $k_{i}$ is coefficient of the weight of indicators for assessing production resources; $M_{1}$ - the coefficient of providing the enterprise with material resources; $M_{2}$ - coefficient of useful expenditure of material resources; $M_{3}$ - material consumption of products; $M_{4}$ coefficient of serviceability of fixed assets; $M_{5}$ - return on assets; $M_{6}$ - coefficient of production mechanization; $M_{7}$ - capital-labor ratio.

Labor resources $\left(R_{L}\right)$ are determined by the formula:

$R_{F}=\left(k_{1} \times L_{1}\right)-\left(k_{2} \times L_{2}\right)+\left(k_{3} \times L_{3}\right)+\left(k_{4} \times L_{4}\right)+\left(k_{5} \times L_{5}\right)$,

where, $k_{i}$ is coefficient of weight of indicators of assessment of labor resources; $L_{1}$ - the coefficient of the turnover of employees; $L_{2}$ - the coefficient of the turnover of dismissed workers; $L_{3}$ - the coefficient of the total turnover of employees; $L_{4}$ - staff turnover rate; $L_{5}$ - labor productivity.

For the state and effectiveness of resource potential management and assessment of the degree of influence of enterprise resources on the formation of agricultural enterprise results, the cumulative indicator of effectiveness of the enterprise's resource potential management is used. The basic values for calculating the cumulative indicator of the level of effectiveness of resource potential management are indicators of the level of effectiveness of management of resource potential components and corporate strategic goals (Vasylyk, 2018).

Unit indicators are determined by the formula:

$q_{i}=\frac{q_{\text {ass }}}{q_{\text {bas }}}$,

where, $q_{i}$ is single indicators within each of the components of the RPE (resource potential of the enterprise) for a certain period; $q_{\text {ass }}$ - a point assessment of each indicator of the effectiveness of using the components of the RPE for a certain period (max 10 points); $q_{\text {bas }}$ - the baseline score of each indicator within the components of the RPE for a certain period ( $\max 10$ points); $j$ - the number of individual indicators within each of the components of the RPE.

Group indicators are determined by the formula:

$I_{g r}=V_{j} \times q_{i}$,

where, $I_{g r}$ is group indicators within each of the components of the RPE for a certain period; $V_{j}$ - the coefficient of the weight of a single indicator within each of the components of the RPE $(\Sigma 1)$.

Complex indicators are determined by the formula:

$K_{i}=\sum_{i=1}^{n} I_{g r}$,

where, $K_{i}$ is a complex indicator for assessing the effectiveness of RPE management according to the relevant components; $n$ - the number of group indicators within each of the components of the RPE.

4. The integral indicator is determined by the formula:

$I_{I}=\sum_{i=1}^{5} V_{i} \times K_{i}$, 
where, $I_{I}$ is an integral indicator of the effectiveness of RPE management; Vi - weighting coefficient of each of the components of the RPE ( $\Sigma 1-5 \times 0,2$ is recommended).

Scale and interpretation of the level of efficiency of management of the resource potential of the enterprise:

$8 \leq I_{i} \leq 10$ - high level of management efficiency of RPE (components of RPE)

$6 \leq I_{i} \leq 7,9$ - sufficient level of efficiency of RPE management;

$4 \leq I_{i} \leq 5,9$ - average level of efficiency of RPE management;

$2 \leq I_{i} \leq 3,9$ - satisfactory level of efficiency of RPE management;

$0 \leq I_{i} \leq 1,9$ - low level of efficiency of RPE management.

The proposed integrated assessment allows comparing the achieved level of effectiveness of management of both the enterprise's resource potential as a whole and its individual components; to better understand the situation, the values are taken for a certain period not less than 5 years.

The strategic management and use of the resource potential of agricultural enterprises require first of all to justify the prospects of its further development based on available resources: the analysis of available resource potential and level of its utilization, definition of lost resource potential opportunities, optimization of the structure of corporate resources and sources of their formation; assessment of risks of additional resource involvement.

The process of management of the agricultural enterprises' resource potential consists of the following major components: subjects, objects, purpose and organizational and economic mechanism of management. The purpose of resource potential management is to improve the enterprise's competitive position and, as a result, increase profits and profitability to ensure further development and competitiveness. The subject of resource potential management is the management of a particular enterprise. The objects of management are the sources of its formation, cost estimate, structure, resource combination, resource conservation technologies and efficiency of the use of resource potential, which is determined by its assessment.

The strategy of the enterprise's resource potential formation implies a set of basic provisions which are the foundation for choosing the sources and determining the scope of resource supply, as well as for the effective allocation of resources according to the areas of use (Hrosul \& Fylypenko, 2014).

The purpose of developing and implementing a strategy for the resource potential management is to form a set of resources ensuring the enterprise's sustainable development.

Ensuring the optimal and rational level of the use of resource potential of business entities is an essential component of strategic management. The formation of sufficient resource potential is a prerequisite for the strategic management procedure.

The process of developing a strategy for the management of the agricultural enterprises' resource potential with due regard to the specific aspects of its production and sales process represents a sequence of the following stages: strategic analysis; development of strategic goals; formation of strategic standards; choice of strategy depending on the level of resource potential; development of measures ensuring the effective implementation of 
the strategy; assessment and control of the proposed strategy.

Building a strategy for the resource potential management begins with the analysis of external and internal factors. The environmental monitoring is aimed at identifying threats and opportunities that need to be considered for planning strategic activities. The current quantitative and qualitative characteristics of corporate resources should be referred to the most important internal factors. At this stage, the obtained results enable determining the level of the enterprise's resource potential.

The next step is to develop strategic goals and strategic standards based on the data obtained. The system of strategic goals must provide for the minimum to target level of the enterprise's resource potential to form a sufficient amount of resources and optimize their structure. Besides, the strategic standards of the enterprise are formed, specifying the strategic goals and justifying the basis for making management decisions.

At the third stage, the basic strategy for the enterprise's resource potential management is chosen; the development of such a strategy takes into account the enterprise's current resource potential, market position and state of the external environment. Within the framework of the chosen strategy, the structure and composition of resource potential are formed, which will ensure the sustainable development, efficient use and reproduction. The process of the formation of resource potential of the enterprise is one of the directions of its strategy and implies the creation of a system of resources so that their interaction results in the successful achievement of the enterprise's strategic, tactical and operational goals. The procedure for determining the amount of strategic resources required to implement the enterprise's development strategy is a key element of the process of the enterprise's strategy development.

The fourth stage implies the development of measures aimed at the efficient implementation of the strategy. The system of measures allows forming the enterprise's resource potential with due regard to the value priorities of its activities; these measures are based on planning and forecasting. The forecasts including the qualitative parameters of available resources are reflected in the strategic plan. To implement the strategy of resource potential formation, the main tactical steps are determined, such as the development of several scenarios of the situation. After choosing the best option, the current plans are drawn up.

The fifth stage of the resource potential management strategy is to assess and monitor the implementation of the strategy by means of comparing the results of work with the goals to be sought. This process ensures a stable feedback between the process of achieving goals and the actual goals to be sought; this interrelation is used to adjust the strategy. To be efficient, the assessment should be carried out systematically and continuously. The strategy assessment indicators depend on the type of strategy; the strategy itself can be adjusted based on the assessment results.

The management decisions must be reasonable, purposeful, specific as to the quantity and quality, legitimate, optimized, timely, comprehensive and flexible. The adopted management decisions will perform managing, coordinating and mobilizing functions only if this is the case. Timely control is especially important in the unstable economic environment, because the efficient operation of the resource management system and the development strategy availability will help ensure and maintain the successful development of agribusiness. 


\section{Determination of Efficiency of the Agricultural Enterprises' Resource Potential Management and The Development of Its Strategic Management}

Increasing the efficiency of use of the agricultural sector resource potential which ensures the creation of the consumption fund is a prerequisite for the development of national economy. Therefore, it is extremely important to determine the composition and structure of the business entity's resource potential as part of a holistic economic system with due regard to the types of management and ownership. It will enable establishing structural changes in the resource potential, which will directly affect the efficiency of production activities and the gross output of enterprises.

The agricultural sector is characterized by seasonality, which is bound to influence the resource potential formation; its ratio of structural elements will be constantly changing in different periods. These changes will reflect the pattern of the enterprise's development, but they must ensure the system's effective operation as a whole (Matsybora, 2014).

The indicators of the agricultural enterprise's resource availability change differently, sometimes just to the opposite, which determines the efficiency of using the resource potential of agricultural enterprises.

The formation of resource potential of agricultural enterprises takes place under the conditions of reduced land development and land supply, which is objectively because of the economic situation and transition to the intensive economic growth in agriculture. In other words, the development of the resource potential of agricultural enterprises must be ensured by means of more efficient use of resources due to the scientific and technological progress and latest forms of production organization.

Increasing the efficiency of use of the resource potential of agricultural enterprises plays a pivotal role in addressing successfully the economic and social problems and achieving the main purpose of production (i. e. the increase of profitability). The state of the economic development of agricultural enterprises largely depends on the efficiency of use of resource potential, so its regular development is not only of methodological, but also of practical significance.

To carry out analysis according to the proposed method (Vasylyk, 2018), we have chosen as an object of analysis the State Enterprise "Experimental Farm "ELITNE" of the Plant Production Institute named after V. Ya. Yurieva of the National Academy of Agrarian Sciences of Ukraine" located in the Kharkiv district of the Kharkiv region and supplying consumers with high quality crop products, including the elite seeds of agricultural crops. The enterprise develops new crop production technologies, sets up experiments in the fields, as well as develops new approaches to the seed production (Table 1).

Table 1: The dynamics of the resource potential and the efficiency of its use in the State Enterprise "Experimental Farm "ELITNE" of Plant Production Institute named after V. Ya. Yurieva of the National Academy of Agrarian Sciences of Ukraine", 2014-2019.

\begin{tabular}{|l|c|c|c|c|c|c|}
\hline Indicators & 2014 & 2015 & 2016 & 2017 & 2018 & 2019 \\
\hline $\begin{array}{l}\text { Gross production (at constant 2016 prices), } \\
\text { thousand UAH. }\end{array}$ & 3725,90 & 3411,86 & 3343,90 & 3060,42 & 3519,73 & 3584,25 \\
\hline Total agricultural land, thousand hectares. & 1819 & 1819 & 1819 & 1819 & 1819 & 1819 \\
\hline Average annual number of employees, people. & 72 & 66 & 61 & 58 & 61 & 52 \\
\hline
\end{tabular}




\begin{tabular}{|l|c|c|c|c|c|c|}
\hline Indicators & 2014 & 2015 & 2016 & 2017 & 2018 & 2019 \\
\hline Load per worker of agricultural land, hectares. & 25,3 & 27,6 & 29,8 & 31,4 & 29,8 & 35,0 \\
\hline Funding capacity, thousand UAH. & 318,0 & 330,2 & 342,8 & 331,0 & 325,8 & 314,0 \\
\hline Capital-labor ratio, thousand UAH. & 80,3 & 91,0 & 102,2 & 103,8 & 97,1 & 109,8 \\
\hline Return on assets, RUB. & 0,64 & 0,57 & 0,54 & 0,51 & 0,59 & 0,63 \\
\hline Capital intensity, UAH. & 1,55 & 1,76 & 1,86 & 1,97 & 1,68 & 1,59 \\
\hline
\end{tabular}

By the investigated agro-formation not affected the general tendency to reduce the agricultural area; during six years of studies its agricultural area did not change. After the number of workers engaged in agricultural activities decreased by 20 people, the workload per agricultural worker increased from 25.3 hectares in 2014 to 35 hectares in 2019. The studies show that as of 2019, the enterprise obtained 3584.25 thousand hryvnias of gross output (in constant prices of 2016), which was 3.8\% less than the same indicator of 2014 because of the reduction in crops. The study reveals that the level of return on assets has slightly decreased compared to the same indicator of the base period, and the capital-labor ratio also shows a decreased level during the study period. In general, there were great fluctuations and no sustainable development of the level of resource potential availability and the efficiency of its use; therefore, there is a need to develop a general resource potential management strategy.

Assessing the efficiency of the use of resource potential as an integral part of the internal strategic environment is an important area of analyzing the enterprise activities. Recently, there is a tendency to reduce the efficiency of resource potential; at the micro level it has a negative impact on the financial performance of individual economic entities, which emphasizes the importance of the problem raised.

Assessing the efficiency of use of resource potential should consist of the following stages: first, we select the resources that are priorities to the enterprise which activities are under analysis; secondly, we assess the efficiency of use of each resource potential component; thirdly, the efficiency of use of resource potential is assessed as a whole on the basis of calculations done. It is a good practice to compare the actual indicators of efficiency with the reference ones while assessing the efficiency of the use of resource potential. It is understood that the standard value of, say, resource capacity is the minimum amount of resources that the enterprise must own to obtain a unit of a certain type of product or 1 hryvnia of its value in general. If the actual resource capacity is higher than the standard value, the efficiency of use of resource potential is lower than the standard one, and vice versa, lower costs show that the efficiency has been improved.

One of the most important tasks of production development is to ensure production by increasing its efficiency and better use of the enterprise's internal reserves. This requires using fixed assets and production facilities more rationally. The importance of efficient use of the enterprise's resource potential consists in increasing the return on fixed assets, which is complicated nowadays by the rapid change of equipment, as well as increased capital investment to improve working conditions (Pererva \& Nagy, 2018). One of the factors increasing the efficiency of use of the enterprise's fixed assets is to increase the percentage of active fixed assets, machinery and equipment in particular, which will promote both production at relatively low labor costs and increased return on production equipment. As it is shown in Fig. 1, in 2014-2019 there is a tendency towards the reduction of returns 
on assets, and, accordingly, increase in the capital-output ratio of production under the conditions of a constant increase in value of the analyzed enterprise's fixed assets and reduction of gross output value in constant prices of 2016.

$\mathrm{UAH}$

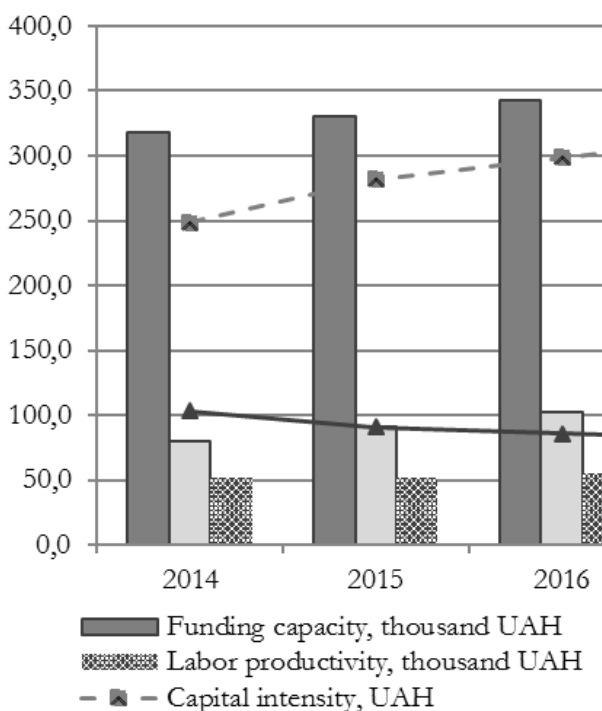

UAH-RUB
20172018

Capital-labor ratio, UAH

$\multimap$ Return on assets, RUB

Fig. 1. The dynamics of the efficiency of using the resource potential in the State Enterprise "Experimental Farm "ELITNE" of the Plant Production Institute named after V. Ya. Yurieva of the National Academy of Agrarian Sciences of Ukraine", 2014-2019.

The maximum gross output value in constant prices of 2016 was obtained in 2014 in the amount of 3,725.90 thousand hryvnias. At the same time, the maximum return on assets (UAH 0.64) and minimum capital-output ratio (UAH 0.51) were obtained in 2017 in the amount of 6020.5 thousand hryvnias and 3060.42 hryvnias respectively.

Productive labor is one of the determinants of a successful enterprise. Productivity can be regarded as a general indicator that characterizes the efficiency of resource use for the output of products. However, the modern economic theory states that it is impossible to accurately determine the role and share of costs of certain resources used for the output of products. Therefore, to determine the production efficiency, the indicator of labor productivity is most often used, although it does not mean that labor is the only source of productivity (Pakhucha, 2015). During a six-year period, labor productivity increased by $33.2 \%$ at the enterprise under study; really, there are some fluctuations, but they are not significant. Labor productivity is sure to be influenced by the enterprise's capital-labor ratio, which has increased by $36.7 \%$, showing a gradual improvement of the efficiency of use of resource potential. We can speak of a positive trend and opportunity to further develop the strategically important resources of the enterprise.

The resource potential efficiency management should be considered as an ancillary stage, which includes such areas as quality and result management. The effective management involves purposeful reproduction; the full use of enterprise resources is ensured only in 
case of economically and socially appropriate ratio of labor resources to logistics, fixed assets first of all; use of advanced, highly productive and environmentally friendly technologies for the output of products; resource enhancement, reproduction and update. After all, well-organized logistics and high quality of basic production assets (both materials and technologies) directly determine the effectiveness, security and development of the enterprises' resource potential. The assessment of resource potential management effectiveness is quite an acute issue for each agricultural enterprise, that's why we tested the assessment method offered by Vasylyk N. M. on this particular enterprise.

We calculated the individual, group, complex and cumulative indicators of resource potential management effectiveness at the State Enterprise "Experimental Farm "ELITNE" of the Plant Production Institute named after V. Ya. Yurieva of the National Academy of Agrarian Sciences of Ukraine" for 2014-2019 period. The calculation tables are rather cumbersome, so in our article we represent only the final results of calculations of the effectiveness of management of resource potential and its components at the State Enterprise "Experimental Farm "ELITNE" of Plant Production Institute named after V. Ya. Yurieva of the National Academy of Agrarian Sciences of Ukraine" achieved during the specified period (Table 2).

Table 2: The achieved level of efficiency of resource potential management and its components in the State Enterprise "Experimental Farm "ELITNE" of Plant Production Institute named after V. Ya. Yurieva of the National Academy of Agrarian Sciences of Ukraine", 2014-2019.

\begin{tabular}{|l|c|c|c|c|c|c|}
\hline Complex indicators of the level of management efficiency & 2014 & 2015 & 2016 & 2017 & 2018 & 2019 \\
\hline Resource potential $\left(I_{R}\right)$ & 5,20 & 6,11 & 6,38 & 6,20 & 6,16 & 6,37 \\
\hline Potential of fixed assets $\left(I_{F A}\right)$ & 4,58 & 5,02 & 5,69 & 6,87 & 6,55 & 7,05 \\
\hline Potential material resources $\left(I_{M}\right)$ & 5,64 & 5,57 & 5,89 & 5,05 & 5,29 & 5,79 \\
\hline Labor potential $\left(I_{L}\right)$ & 7,14 & 7,89 & 7,74 & 7,89 & 8,02 & 8,59 \\
\hline Financial potential $\left(I_{F}\right)$ & 3,41 & 6,59 & 6,95 & 5,11 & 4,58 & 3,89 \\
\hline Information potential $\left(I_{I N F}\right)$ & 5,24 & 5,48 & 5,62 & 6,08 & 6,36 & 6,52 \\
\hline
\end{tabular}

Thus, we fill the action matrix on the basis of the above calculations in accordance with the effectiveness of management of resource potential and its components at the State Enterprise "Experimental Farm "ELITNE" of Plant Production Institute named after V. Ya. Yurieva of the National Academy of Agrarian Sciences of Ukraine" achieved in 20142019.

The State Enterprise "Experimental Farm "ELITNE" of Plant Production Institute named after V. Ya. Yurieva of the National Academy of Agrarian Sciences of Ukraine" had positive trends in 2014-2019 the management of both individual components of resource potential, and the enterprise's resource potential as a whole. As can be seen from the action matrix, there are reserves for improving the effectiveness of management of both resource potential and all its components according to the achieved level of resource potential management effectiveness. In general, the level of resource potential management effectiveness did not reach its climax during the analyzed period of 20142019; it is only sufficient (Table 3). 
Table 3: Matrix of actions in accordance with the achieved level of efficiency of resource potential management and its components in the State Enterprise "Experimental Farm "ELITNE" of Plant Production Institute named after V. Ya. Yurieva of the National Academy of Agrarian Sciences of Ukraine", 2014-2019.

\begin{tabular}{|c|c|c|c|c|c|c|}
\hline RPE level & 2014 & 2015 & 2010 & 2017 & 2018 & 2019 \\
\hline $8 \leq I_{I} \leq 10$ - high level of management efficiency of RPE & - & - & - & - & $I_{L}$ & $I_{L}$ \\
\hline $6 \leq I_{I} \leq 7.9$ - sufficient level of efficiency of RPE management & $I_{L}$ & $\begin{array}{l}I_{L} \\
I_{F}\end{array}$ & $\begin{array}{l}I_{L} \\
I_{F}\end{array}$ & \begin{tabular}{|c}
$I_{F A}$ \\
$I_{L}$ \\
$I_{I N F}$ \\
\end{tabular} & $\begin{array}{l}I_{\mathrm{FA}} \\
I_{I N F}\end{array}$ & $\begin{array}{l}I_{F A} \\
I_{I N F}\end{array}$ \\
\hline $4 \leq I_{I} \leq 5.9$ - average level of efficiency of RPE management & \begin{tabular}{|c|}
$I_{F A}$ \\
$I_{M}$ \\
$I_{I N F}$ \\
\end{tabular} & \begin{tabular}{|c|}
$I_{\mathrm{FA}}$ \\
$I_{M}$ \\
$I_{I N F}$ \\
\end{tabular} & \begin{tabular}{|c|}
$I_{F A}$ \\
$I_{M}$ \\
$I_{I N F}$ \\
\end{tabular} & $\begin{array}{c}I_{M} \\
I_{F}\end{array}$ & $\begin{array}{l}I_{M} \\
I_{F}\end{array}$ & $I_{M}$ \\
\hline $\begin{array}{l}2 \leq I_{I} \leq 3.9 \text { - satisfactory level of efficiency of RPE } \\
\text { management }\end{array}$ & $I_{F}$ & - & - & - & - & $I_{F}$ \\
\hline $0 \leq I_{I} \leq 1.9$ - low level of efficiency of RPE management & - & - & - & - & - & - \\
\hline
\end{tabular}

From 2014 to 2016, the effectiveness of management of fixed assets, material resources and information potential remained at the average level. However, if positive trends in the financial and economic position are ensured, there will be a real opportunity in the future to improve the resource potential management, but this requires the involvement of internal and external sources and effective measures to improve the management. As we can see, during 2017-2019 the level of effectiveness of fixed asset potential management and information potential became sufficient, which suggests that the measures to improve efficiency were taken, but there is still a possibility for further improvement. However, as for the level of material resource management effectiveness, it remained average during the study period. This situation requires taking strategic measures to change the situation. The most positive trend was observed when studying the labor potential management effectiveness; its level was sufficient in 2014-2017 and high during the last two study periods, so only supportive measures are needed to maintain the achieved level in the future. The level of financial potential management effectiveness demands greatest attention and improvement. Thus, it fluctuated quite strongly during the study period, from a satisfactory level in 2014 to a sufficient level in 2015-2016 and an average one in 2017-2018; and during the last year of the study it was again satisfactory, the same as in the base period, which primarily indicates the ineffectiveness of this resource component management in a changing environment and lack of risk protection measures. In this case, both urgent radical measures to improve the financial potential management and a comprehensive system of financial and economic recovery are needed.

To further increase the effectiveness and intensify the economic development of business entities, the creation of a system of the strategic management of resource potential should be considered. Under the market development conditions, this well-developed system gives wider advantages for making correct administrative decisions on all activity vectors. In this case, the strategic management can not be implemented without due regard to the impact of external environment and its changes, because the agricultural enterprise needs to both make market forecasts and take into account the strategy of the area's social and economic development (Kazambayeva, Aiesheva \&Yesengaliyeva, 2020). These issues of concern are still studied by many senior executives. However, in almost all studies the 
whole set of problems related to the ambiguity of theoretical development of the system of strategic management of resource potential remains unsolved and gets the applied decision-making in the field of strategic management system formation more difficult. The transformation of economic development conditions and increased dynamics of factors of external environment development present new challenges and highlight the need for merging the strategic management concepts. The concept of dynamic opportunities, developed in response to the escalating competition looks promising. The dynamic nature of the business entity's capacities indicates the possibility of their adaptation to the conditions of macro environment; in particular, such capacities are related to the rapid development of external and internal potentials of agricultural enterprises.

Combining resources to create necessary opportunities and competencies can be regarded as a part of the system of creating corporate values; it must be synergistically integrated with the corporate value systems to dynamically maintain competitive advantages and achieve positive results (Fensterseifer, 2009).

The strategic management of agricultural enterprises allows defining the concept of strategy of management of the agricultural enterprise's resource potential as a set of management decisions that constitute a program of use and development of the enterprise's resource potential, which ensures a qualitative approach to achieving competitiveness and contributes to the sustainable development of the entire enterprise. The strategic management of resource potential must take into account the specific aspects of enterprise activities and accumulated resource potential.

Based on the conducted study and state of current resource potential, the system of management of agricultural enterprises' resource potential has been formed with due regard to a set of rules, regulations, principles and tasks of strategic management (Fig. 2). The main requirements for the system of strategic management of resource potential are as follows: priority of the agricultural enterprise's long-term development; business entity's increased competitiveness in market conditions; development of the agricultural enterprise's social infrastructure; information and financial potential improvement. An important priority in the implementation of the strategy of management of the agricultural enterprise's resource potential is the concentration of relevant resources and efforts to achieve the efficiency of production and economic activities and socio-economic development of the business entity, aimed at promoting efficiency and prioritizing the support of the enterprise's sustainable development. 


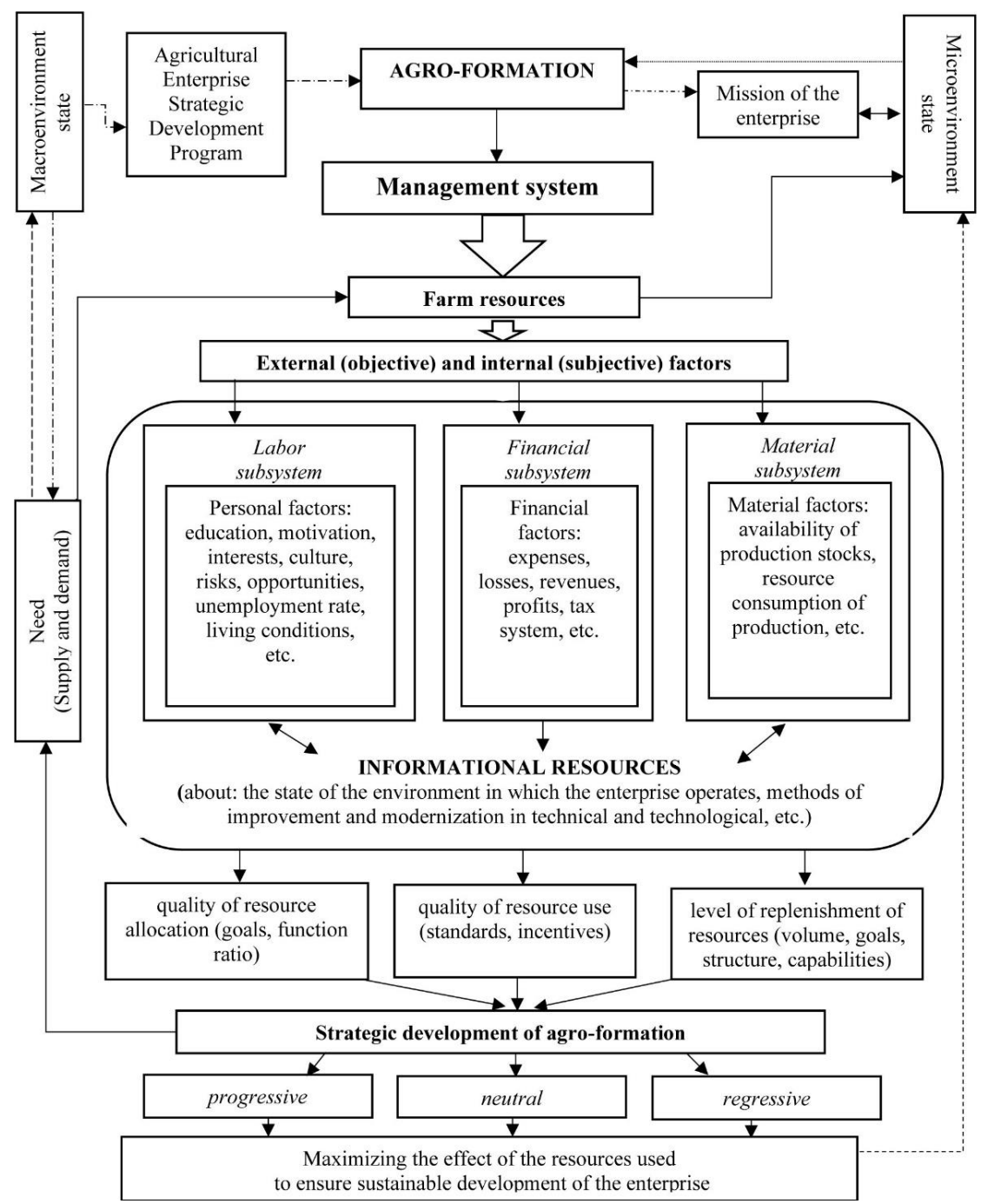

Fig. 2. The system of strategic management of the resource potential of agricultural formation.

\section{Discussion of The Results of Analysis of Enterprise Competitiveness in The Agricultural Market in The Context of Globalization}

The proposed system clearly demonstrates the process of formation of the agricultural enterprise's resource potential, which has a managerial effect on its economic processes and strategic development thanks to a functional subsystem aimed at fulfilling effectively the basic functions of the agricultural enterprise. The system was developed based on the task of rational formation of the agricultural enterprise's resource potential and competitiveness, which facilitates the choice of effective strategy depending on the enterprise's production and economic activities and development (progressive, neutral or regressive strategic development). The proposed system is a tool for developing a specific 
aspect of the agricultural enterprise's resource potential development and effective implementation of the management strategy with due regard to the macro environment variation.

This approach to the development of a system of strategic management of resource potential is proposed for agricultural enterprises and can combine resources and integrate production, processing and sales. The internal resources are combined with the external resources by means of cooperative relationships, in the process of creation and ongoing centralization of opportunities and competencies necessary to continually meet the needs of consumers. The resource potential of agricultural enterprises is available only for the business entities with similar characteristics; besides, it makes the process of attracting external resources continuous and more intensive. The effectiveness of strategic management of the agricultural enterprise's resource potential is measured by the extent to which it can promote the creation and maintenance of competitive advantages in a changing market environment.

The areas of implementation of the proposed measures to develop the resource potential of agricultural enterprises should be based on a set of factors in order for the producers to build a strategic plan for the use and recovery of natural and material resources, ensure the efficient use of resources and introduce innovative resource-saving technologies. The development of agricultural enterprises should include system restructuring and creation of favorable conditions for the activities of business entities in the external environment based on the development and implementation of a strategy for the management of corporate resource potential.

\section{Conclusion}

The strategically oriented resource potential of agricultural enterprises is the availability of a sufficient amount of quality resources for the economic entity and strategic competencies in the management, formation and implementation of the enterprise's goal achievement strategy. The availability and quality of resources and competencies determine the configuration of possible areas of strategic development of a specific enterprise. The process of management of the agricultural enterprise's resource potential consists of the following successive steps: definition of the mission and goals for different time periods, analysis of the enterprise's current state and resource potential, assessment of opportunities to attract resources or development of alternative ways of using available resources, development of resource strategy and strategic plans consistent with the general business goal, implementation of the chosen strategy, detection of deviations and strategy adjustment as needed.

In the course of the study, it was established based on the indicators of the selected agricultural enterprise that in general the available resource potential and efficiency of its use fluctuated strongly and there was no sustainable development. The individual, group, complex and cumulative indicators of the effectiveness of management of the agricultural enterprise's resource potential were calculated, and on the basis of the above calculations an action matrix was filled according to the achieved effectiveness of management of resource potential and its components. The measured level of effectiveness is only sufficient, so there is a need to develop a general strategy for the resource potential 


\section{management.}

The proposed system of strategic management of the agricultural enterprise's resource potential demonstrates the process of formation of the resource potential, which has a managerial effect on the enterprise's economic processes and strategic development, and is aimed at fulfilling effectively the basic functions of the agricultural enterprise. The system was developed based on the task of rational formation of the agricultural enterprise's resource potential and competitive advantages. Depending on the enterprise's production and economic activities and development, it is proposed to use progressive, neutral or regressive strategic development.

The resource strategy development, current risk analysis, identification of shortcomings of economic activities and their mitigation can determine the areas for the strategic improvement of activities, competitiveness and effectiveness of agricultural enterprises. The development of strategic management of resource potential is a key factor in achieving success by the producer. The modern system can be practically applied by agricultural enterprises at the stage of developing a long-term strategy and tactical plans to attract, allocate and use necessary resources in order to optimize effectiveness. In the future, this area can be further investigated to create mathematical models of the resource potential of agricultural enterprises by calculating the effectiveness of optional ways to attract resources and determining the criteria for choosing the best one in accordance with the current strategy.

\section{References}

Aranchii, V.I., Zoria, O.P., Riznychenko, O.A. (2019). Riven resursnoho potentsialu i efektyvnosti hospodariuvannia ta chynnyky yikh vplyvu na formuvannia stratehii rozvytku ahrarnykh pidpryiemstv. [The level of resource potential and efficiency of management and factors of their influence on formation of strategy of development of the agricultural enterprises]. Actual problems of innovative economy. No 2. pp. 26-30. (in Ukrainian).

Bohatska, N., Kovalchuk, O. (2012). Resursnyi potentsial pidpryiemstva: sutnist ta stratehiia vykorystannia. [Resource potential of the enterprise: the essence and strategy of use]. Materials Int. scientific-practical conf. "Modern Scientific Acbievements - 2012". URL: http://rusnauka.com/4_SND_2012/Economics /10_98032.doc.htm. 5428 (data access: 02.03.2021). (in Ukrainian).

Burkovska, A., \& Romanchyk, M. (2016). The ensuring of the competitiveness of the enterprises through the strategic human resource management. Agricultural and Resource Economics: International Scientific EJournal. No 2(4). pp. 43-51.

Collins, Christopher, J. (2020). Expanding the resource based view model of strategic human resource management. The International Journal of Human Resource Management. Vol.32. pp. 331-358.

Chyrva, O.H. (2016). Umovy ta chynnyky stratehichnoho upravlinnia resursnym potentsialom silskohospodarskykh pidpryiemstv. [Conditions and factors of strategic management of resource potential of agricultural enterprises]. Efficient economy. No 6. URL: http:/ / www.economy.nayka.com.ua/?op $=1 \& z=5022$. (data access: 25.02.2021). (in Ukrainian).

Demchenko, O.V. (2017). Stratehichne upravlinnia rozvytkom resursnoho potentsialu ahrarnykh pidpryiemstv v umovakh minlyvoho ekonomichnoho seredovyshcha. [Strategic management of the development of the resource potential of agricultural enterprises in a changing economic environment]. Ukrainian Journal of Applied Economics. Tom 2. No 3. pp. 39-50. (in Ukrainian).

Dudnyk, O.V. (2016). Investytsiini stratehii pidvyshchennia efektyvnosti vykorystannia resursnoho potentsialu ahrarnykh pidpryiemstv. [Investment strategies to increase the efficiency of using the resource potential of agricultural enterprises]. Economics of agro-industrial complex. No 5. pp. 79-87. (in Ukrainian). 
Fensterseifer, Jaime, Evaldo (2009). Strategic resources and sustainability of competitive advantages in industrial clusters: towards a general analytical framework. Encontro Da Associação Nacional de PósGraduação em Administração. Vol. 33, pp. 1-14.

Feshchenko, N. (2015). Programme-aimed management in the agrarian sector of economics. Global and national economic problems. Vyp. 5. pp. 255-265. (in Ukrainian).

Hrosul, V.A., Fylypenko, O.M. (2014). Stratehichne upravlinnia resursnym potentsialom torhovelnoho pidpryiemstva. [Strategic management of resource potential of a trading company]. Trade, commerce, entrepreneurship. Vyp. 17. pp. 28-32. (in Ukrainian).

Kazambayeva, A.M., Aiesheva, G.A., Yesengaliyeva, S.M. (2020). Sustainable development of agricultural production based on the use of the resource potential of the region. Journal of Environmental Management and Tourism. Vol. 10, No 7, pp. 1478-1485.

Khromushyna, L., Konieva, I., Skrypnyk, Y., \& Shalyhina, I. (2018). Formation of resurce potential of agrarian enterprises on the principles of ecological and economic security. Journal of Environmental Management and Tourism. Vol. 9 No 5. pp. 979-986.

Kostyrko, L., Solomatina, T., Chernodubova, E., \& Khromiak, V. (2020). Analysis and estimation of the efficiency of the use of resource potential agricultural enterprises. Financial and credit activity: problems of theory and practice. Vol. 3 No. 34. pp. 294-302. (in Ukrainian).

Kustrich, L.O. (2017). Osnovni zasady pidvyshchennia efektyvnosti stratehichnoho upravlinnia ta vykorystannia potentsialu silskohospodarskykh pidpryiemstv. [Basic principles of improving the efficiency of strategic management and using the potential of agricultural enterprises]. Scientific Bulletin of Kherson State University. Vyp. 27. Ch.2. pp. 19-22. (in Ukrainian).

Malinoshevsk, K. (2019). Strategy for development of agro-industrial complex and market of agricultural land in Ukraine. New stages of development of modern science in Ukraine and EU countries: monograph / edited by authors. 2nd ed. Riga, Latvia : "Baltija Publishing", 2019. 528 p.

Matsybora, V.I. (2014). Efektyvnist vykorystannia resursnoho potentsialu silskohospodarskykh pidpryiemstv. [Efficiency of using the resource potential of agricultural enterprises]. Scientific Bulletin of the National University of Bioresources and Nature Management of Ukraine. Vyp. 200(2). pp. 176-182. (in Ukrainian).

Mikhaylik, D.P. (2017). Management strategy of the financial potential. National Economic Development and Modernization: experience of Poland and prospects for Ukraine: collective monograph. Vol. 2. Poland: "Izdevnieciba "Baltija Publishing". 348 p.

Nadzhib, F. (2020). Osoblyvosti formuvannia struktury resursnoho potentsialu pidpryiemstva z pozytsii konkurentospromozhnosti. [Features of the formation of the structure of the resource potential of the enterprise from the standpoint of competitiveness]. Scientific view: economics and management. №1 (67). pp. 95-98. (in Ukrainian).

Oliinyk, L.V. (2017). Stratehichni napriamy upravlinnia resursnym potentsialom pidpryiemstva. [Strategic directions for managing the resource potential of the enterprise]. Global and national economic problems. Vyp.19. pp. 214-218. (in Ukrainian).

Pakhucha, E.V. (2015). Produktyvnist pratsi v silskohospodarskykh pidpryiemstvakh Kharkivskoi oblasti. [Labor productivity in agricultural enterprises of the Kharkiv region]. Agricultural and Resource Economics: International Scientific E-Journal. Vol. 1, No 2, pp.76-84. (in Ukrainian).

Pererva, P., Nagy, S. (2018). Efficiency of use of resource potential. Strategically-innovative development of the subjects of the economic system in the conditions of globalization: Materials Int. scientific-practical int.-conf. (Kremenchuk, September 7-9, 2018). Kremenchuk. pp. 82-86.

Polyanin, A.V. \& Dokukina I.A. (2016). Implementation of strategic management in agricultural organizations: problems and prospects. Journal of Agricultural and Socio-Economic Sciences. Vol. 7(55). pp. 54-61.

Romanii, Y. (2019). Formuvannia modeli stratehichnoho upravlinnia resursnym potentsialom pidpryiemstv ahrarnoi haluzi. [Formation of a model of strategic management of resource potential of agricultural enterprises]. Economic Bulletin of NTUU "KPI". No 16. pp. 65-70.

Salunm, M. (2012). Structure of industrial enterprise resource potential. Municipal Economy of Cities. (102), pp.170-178.

Senchuk, I.I. (2018). Osoblyvosti transformatsii resursnoho potentsialu ahrarnykh pidpryiemstv. [Features of transformation of resource potential of agrarian enterprises]. Ukrainian Journal of Applied Economics. Tom 3. No 4. pp. 29-34. (in Ukrainian). 
Shamanska, O.I. (2016). Systema otsinky efektyvnosti upravlinnia resursnym potentsialom pidpryiemstv APK. [System for evaluating the effectiveness of resource management of agricultural enterprises.] Efficient economy. No 2, URL: http://www.economy.nayka.com.ua/?op=1\&z=4776 (data access: 04.03.2021). (in Ukrainian).

Shynkovych, A.V. (2019). Tekhnolohii otsiniuvannia rezultatyvnosti orhanizatsiino-informatsiinoho zabezpechennia antykryzovoho upravlinnia ahroformuvan. [Technologies for evaluating the effectiveness of organizational and information support of crisis management of agricultural formations]. Economy. Management. Business. No 4(30). pp. 92-102. (in Ukrainian).

Sievidova, I.O. (2018). Faktory vplyvu na funktsionuvannia optovykh rynkiv ovochevoi produktsii. [Factors influencing the functioning of the wholesale markets for vegetable products]. Ahrosvit. 2, pp. 28-32. (in Ukrainian).

Smolych, D.V., Tymoshuk, I.V. (2020). Resursnyi potentsial pidpryiemstva: sutnist, skladovi ta model upravlinnia $\mathrm{v}$ suchasnykh umovakh hospodariuvannia. [Resource potential of the enterprise: essence, components and management model in modern business conditions]. Economic space. №153. pp. 75-82. (in Ukrainian).

Tereshchenko ,S.I. (2015). Inventaryzatsiia ta resursna pasportyzatsiia ahrarnykh formuvan. [Inventory and resource certification of agricultural formations]. Economics of agro-industrial complex. №2. pp. 43-52. (in Ukrainian).

Tranchenko, L., Petrenko, N., Kustrich, L., Parubok, N., \& Tranchenko, O. (2018). Strategic management optimization of the regional agricultural sector by means of modern forecast modeling instruments. Problems and Perspectives in Management. №16(4). pp. 64-74.

Ulianchenko, O.V. (2009). Resource potential of the agricultural sector of the economy of Ukraine: management aspect: monograph. Sumy: Dovkillia. 383 p. (in Ukrainian).

Vasylyk, N.M. (2018). Otsinka efektyvnosti upravlinnia resursnym potentsialom pidpryiemstva. [Evaluation of the effectiveness of resource potential management of the enterprise]. Economic analysis. Vol. 28. No 3. pp. 154-161. (in Ukrainian).

Viatkina, T.H. (2014). Metodolohiia rozroblennia stratehii upravlinnia resursnym potentsialom silskohospodarskykh. [Methodology for developing a strategy for managing the resource potential of agricultural]. Economy and state. No 6. pp. 68-73. (in Ukrainian).

Zhmailova, O., Zhytnyk, T., Babytska, O., Prykhodko, T., \& Bondarenko, R. (2014). Approaches, principles and factors of agricultural enterprises resource potential formation. Kasmera. Vol. 44. No 8. pp.7382. 